\title{
Economic Growth and Air Pollution in Iran During Development Programs
}

\author{
H. Asadikia, R. Oyarhossein, S. Zare and I. Saleh \\ Department of Agricultural Economics, \\ University of Tehran \\ Iran
}

\section{Introduction}

Air pollution means combination of air with gases that lead to decrease in quality of the air. Pollutant elements are Carbon dioxide, Monoxide, Sulfur Dioxide and etc.

Estimated annual losses of mortality due to urban air pollution are 640 million dollars i.e. 5100 billion Rials that is equivalent 0.57 percent of GDP. The disease caused of urban air pollution creates 260 million- dollar or 2100 billion- Rial cost (0.023 percent of GDP) for the economy of Iran. (World Bank, 2005).

Grossman and Krueger (1991) has analyzed relationship between air pollution and economic growth in USA. GNP per each person, time and pollution index were input in that model. Results show that there is relationship like " $U$ " between GNP per each person and $\mathrm{SO}_{2}$ emission.

Lee (1996) has surveyed air pollution in Korea during 1985-92. The effects show that CO and income have relationship as " $U$ " whereas Sulfur Dioxide, $\mathrm{NO}_{2}$ and Ozone did not have it.

Khan (2002) has perused correlation between revenue in each family and CO, NO and Ozone in USA for the year of 1990. One of the important things is that in this research population, labor force, unemployment, literate people, workmen's, housekeeper, rental house that have an effect on pollution, were Exogenous Variables. Consequences expressed that linkage in equation between income and pollution of gasses is inverse.

Pazhoyan and etal (2007) have examined respect of economic growth and air pollution with Kuznets hypothesis in 67 countries with different income. The effect of economic growth, rural population, provision of environment, number of cars, the ratio of summation of export and import on GNP have been surveyed and results emphasized Kuznets curve for environment in those countries.

This study surveys relationship between air pollution and economic growth and also, evaluation of Economical and Social Development Programs in the field of air pollution reduction. For this purpose, the study used data for 1979-2005 from the Balance Sheet Energy (2009), Iran Department of Environment (2009), Central Bank of Iran (2009) and World Development Reports (2008) has been collected. Calculation and estimates is done by Shazam and SPSS packages. 


\section{Methodology}

The estimation of relationship between economic growth and environmental destruction has done by the use of Grossman and Krueger model with some adjustments (Eq. (1))

$$
L N P=\alpha_{0}+\alpha_{1} L N G D P+\alpha_{3} L N G D P^{2}+\alpha_{4} L N c a r+\alpha_{5} L O+\alpha_{6} L N U+\alpha_{7} D_{1}+\alpha_{8} D_{2}+\alpha_{9} D_{3}+\varepsilon
$$

Where LNP: the logarithm of pollution variable (carbon dioxide emissions per capita in thousand tons), LNGDP: the logarithm of GDP per capita in Iran (billion Rials), LNGDP2: the square logarithm of GDP per capita in Iran, LNCAR: the logarithmic number of cars produced and imported, LNO: the logarithm of the degree of openness of an economy (ratio of total exports and imports to GDP), LNU: logarithm of population (thousands), $\mathrm{D}_{1}$ : dummy variable for the function of first Development Program, $D_{2}$ : dummy variable for the function of second Development Program, $\mathrm{D}_{3}$ : dummy variable for the function of third Development Program (in each dummy variables, the number 1 is related to the program years and the number 0 for the other years). For each of the variables some classes are considered, and then the effect of them is investigated by the find results from SPSS package. Many studies done in the field of air pollution considered carbon dioxide emissions as an index of the air pollution and this gas is one of the most important gases leading to climate change and global warming. Additionally, about 72 percent of greenhouse is related to carbon dioxide, so in this study carbon dioxide emission is a criterion for air pollution.

\section{Summary and conclusion}

Study data are time series, so stationary test is done and the result is available in Table (1) that shows two lags are optimal and whereas calculated value is more than critical value the model is stationary.

\begin{tabular}{|l|l|}
\hline Error term & Description \\
\hline data level & Variable \\
\hline-5.835 & AIC criteria \\
2 & Lag length \\
$3.5573^{*}$ & Calculated value \\
-2.57 & Critical value \\
\hline
\end{tabular}

(Source: research findings)

* $10 \%$ significance level

Table 1. Generalized

Dickey - Fuller Unit root test results

Chi-square test shows that there are significant differences in carbon dioxide per capita for various variable levels. Considering the fifth column table (2), when the population is over 60 million people, 100 percent of pollution will be more than five ton. Significant differences exist in different classes of the export and import at one percent level of and when imports increase the level of pollution also increases. It is obvious that the highest pollution level in import and export class is in 40 to 50 billion-dollar level. 


\begin{tabular}{|c|c|c|c|c|c|c|c|}
\hline variable & $\begin{array}{l}\text { variables } \\
\text { Classification }\end{array}$ & $\begin{array}{l}\text { 1-2 ton } \\
\text { (Percent) }\end{array}$ & $\begin{array}{l}\text { 3-4 ton } \\
\text { (Percent) }\end{array}$ & $\begin{array}{l}\text { 3-4 ton } \\
\text { (Percent) }\end{array}$ & $\begin{array}{l}\text { More than } \\
5 \text { ton } \\
\text { (Percent) }\end{array}$ & Total & $\begin{array}{l}\text { Test } \\
\text { Results } \\
\chi^{2}\end{array}$ \\
\hline \multirow{4}{*}{$\begin{array}{l}\text { Country } \\
\text { population }\end{array}$} & $20-30$ & 25 & 0 & 8 & 0 & 7 & \multirow{4}{*}{ **20.87 } \\
\hline & $40-60$ & 50 & 50 & 0 & 0 & 22 & \\
\hline & $50-60$ & 25 & 50 & 33 & 0 & 33 & \\
\hline & More than 60 & 0 & 0 & 59 & 100 & 38 & \\
\hline \multirow{4}{*}{$\begin{array}{l}\text { Total export } \\
\text { and import } \\
\text { (million person) }\end{array}$} & $20000-30000$ & 75 & 25 & 0 & 0 & 18 & \multirow{4}{*}{ **22.02 } \\
\hline & $40000-50000$ & 25 & 25 & 50 & 0 & 34 & \\
\hline & $50000-60000$ & 0 & 37.5 & 16 & 0 & 19 & \\
\hline & $\begin{array}{l}\text { More than } \\
60000\end{array}$ & 0 & 12.5 & 34 & 100 & 29 & \\
\hline \multirow{4}{*}{$\begin{array}{l}\text { GDP in fixed } \\
\text { price } \\
\text { (billion Riala) }\end{array}$} & $100000-200000$ & 100 & 37.5 & 0 & 0 & 25 & \multirow{4}{*}{$* * * 31.16$} \\
\hline & $200000-300000$ & 0 & 62.5 & 59 & 0 & 44 & \\
\hline & $300000-400000$ & 0 & 0 & 41 & 60 & 25 & \\
\hline & $\begin{array}{l}\text { More than } \\
400000\end{array}$ & 0 & 0 & 0 & 33 & 3 & \\
\hline \multirow{4}{*}{$\begin{array}{l}\text { The numbers of } \\
\text { produced and } \\
\text { imported cars }\end{array}$} & $8000-28000$ & 50 & 37.5 & 0 & 0 & 18 & \multirow{4}{*}{ **17.54 } \\
\hline & $28000-48000$ & 0 & 25 & 8 & 0 & 11 & \\
\hline & $48000-68000$ & 0 & 37.5 & 25 & 0 & 22 & \\
\hline & $\begin{array}{l}\text { More than } \\
68000\end{array}$ & 50 & 0 & 67 & 100 & 49 & \\
\hline
\end{tabular}

(Source: research findings), ${ }^{* *} 5 \%, * * * 1 \%$ significance level

Table 2. Estimated effects of different factors on carbon dioxide emissions

Considering table (3) the emissions of $\mathrm{CO} 2$ during various Development Programs is different. In first and second Development Programs pollution emissions is almost equal, while during third Development Program pollution increase has had significant decrease.

The highest effect on pollution is related to economic growth variable. Since increase in economic growth is as an important goal for all government, it is necessary to this reach this goal while sustainable development is considering and environmental damage is at least.

As an illustration the most important variable that has an effect on pollution is GNP after that population has significant effect that Government must control it with training them to protect the environment.

Although summation of import and export on GNP are not punctual, it explains if importing and exporting is done easier, we can hope that productions with high expenditure will be imported without harmful effect on effect on economy of the Iran.

Instead of that we can export productions with competitive advantages.

Also government must supervise the number of cars and consumption of fuel with pollution must be prohibited, rules in big city should be modified and etc.

The of third Development Program had the remarkable effect on falling the pollution. Authorities should expand it if they want to receive sustainable development I the world. 


\begin{tabular}{|c|c|c|c|}
\hline variables & coefficients & $\begin{array}{l}\text { standard } \\
\text { deviation }\end{array}$ & t statistic \\
\hline The logarithm of GDP in fixed price & $-7.7103 * * *$ & 1.729 & -4.458 \\
\hline the logarithm of GDP square in fixed price & $2.842 * * *$ & 0.5672 & 5.011 \\
\hline $\begin{array}{l}\text { The logarithm of total vehicles number produced } \\
\text { and imported }\end{array}$ & 0.0292 & 0.0204 & 1.432 \\
\hline Logarithmic degree of openness in a economy & -0.2879 & 0.0960 & 0.2998 \\
\hline The logarithm of population & $0.3372 * *$ & 0.1491 & 2.262 \\
\hline $\begin{array}{l}\text { dummy variable for the function of first } \\
\text { Development Program }\end{array}$ & $0.200 * * *$ & 0.0394 & 5.079 \\
\hline $\begin{array}{l}\text { dummy variable for the function of second } \\
\text { Development Program }\end{array}$ & $0.2447 * * *$ & 0.0532 & 4.596 \\
\hline $\begin{array}{l}\text { dummy variable for the function of third } \\
\text { Development Program }\end{array}$ & $0.0794 * *$ & 0.0436 & 1.821 \\
\hline Constant coefficient & 2.6196 & 2.249 & 1.165 \\
\hline \multicolumn{4}{|c|}{$\begin{array}{l}\text { R-SQUARE }=0.9494 \quad \text { R-SQUARE ADJUSTED }=0.9270 \\
\text { DURBIN-WATSON }=2.7128 \\
\text { JARQUE-BERA NORMALITY TEST- CHI-SQUARE }(2 \text { DF })=1.6833 \\
\text { P-VALUE }=0.431\end{array}$} \\
\hline
\end{tabular}

Table 3. Estimated logarithmic model

\section{References}

Central Bank of Iran. 2009.

Grossman,G. m. , A. G. Krueger. 1991 .Environmental Impacts of a North American Free Trade Agreement; National Bureau of Economic Research, NBER Working Paper. 3914.

Iran Department of Environment. 2009.

Khanna,N. 2002. The Income Elasticity of Non-point Source Air pollutants: Revisiting the Environmental Kuznets Curve; Economics Letters, 77, 387-392.

Lee, k. and M. Lee. 1996. The Evaluation of the Regional Development Considering Environment, Environmental Economic Review, Vol.5 No.1, pp. 143-188.

Pazhoyan, j. and Moradhasel,N. 2007. Surveying the effect of economic growth on tha air pollution, economic magazine, VOL.7 NO. 4, PP 160-141.

the Balance Sheet Energy. 2009.

UNDP. 2008. Human Development Report 2004 (Energy And The Environment), World Bank 2007b, Baised on DATA from IEA.

www.ttic.ir/new/ Air polution.aspa.

World Bank. 2005. Human Development Report. (www.worldbank.org)

World Development Reports. 2008. 


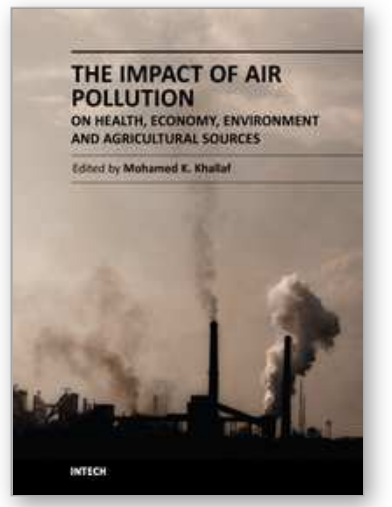

\author{
The Impact of Air Pollution on Health, Economy, Environment and \\ Agricultural Sources \\ Edited by Dr. Mohamed Khallaf
}

ISBN 978-953-307-528-0

Hard cover, 444 pages

Publisher InTech

Published online 26, September, 2011

Published in print edition September, 2011

This book aims to strengthen the knowledge base dealing with Air Pollution. The book consists of 21 chapters dealing with Air Pollution and its effects in the fields of Health, Environment, Economy and Agricultural Sources. It is divided into four sections. The first one deals with effect of air pollution on health and human body organs. The second section includes the Impact of air pollution on plants and agricultural sources and methods of resistance. The third section includes environmental changes, geographic and climatic conditions due to air pollution. The fourth section includes case studies concerning of the impact of air pollution in the economy and development goals, such as, indoor air pollution in México, indoor air pollution and millennium development goals in Bangladesh, epidemiologic and economic impact of natural gas on indoor air pollution in Colombia and economic growth and air pollution in Iran during development programs. In this book the authors explain the definition of air pollution, the most important pollutants and their different sources and effects on humans and various fields of life. The authors offer different solutions to the problems resulting from air pollution.

\title{
How to reference
}

In order to correctly reference this scholarly work, feel free to copy and paste the following:

H. Asadikia, R. Oyarhossein, S. Zare and I. Saleh (2011). Economic Growth and Air Pollution in Iran During Development Programs, The Impact of Air Pollution on Health, Economy, Environment and Agricultural Sources, Dr. Mohamed Khallaf (Ed.), ISBN: 978-953-307-528-0, InTech, Available from: http://www.intechopen.com/books/the-impact-of-air-pollution-on-health-economy-environment-andagricultural-sources/economic-growth-and-air-pollution-in-iran-during-development-programs

\section{INTECH}

open science / open minds

\section{InTech Europe}

University Campus STeP Ri

Slavka Krautzeka 83/A

51000 Rijeka, Croatia

Phone: +385 (51) 770447

Fax: +385 (51) 686166

www.intechopen.com

\section{InTech China}

Unit 405, Office Block, Hotel Equatorial Shanghai

No.65, Yan An Road (West), Shanghai, 200040, China

中国上海市延安西路65号上海国际贵都大饭店办公楼 405 单元

Phone: +86-21-62489820

Fax: +86-21-62489821 
(C) 2011 The Author(s). Licensee IntechOpen. This chapter is distributed under the terms of the Creative Commons Attribution-NonCommercialShareAlike-3.0 License, which permits use, distribution and reproduction for non-commercial purposes, provided the original is properly cited and derivative works building on this content are distributed under the same license. 